\title{
Response of Different Explants for Callus Induction in Cucumber
}

Hasina Sultana, Lutfun Nahar, M. Mofazzal Hossain, Totan Kumar Ghosh, and Md. Sanaullah Biswas

\section{ABSTRACT}

In vitro regeneration of cucumber is relatively difficult for genetic improvement. In this regard, different concentrations of growth regulators and three types of explants (cotyledon, hypocotyl and leaf disc) were investigated for their efficiency on callus induction potential. Among different explants explored for callus induction with different concentrations of 2,4-dichlorophenoxyacetic acid (2,4-D), leaf disc responded earlier (4.67 days) and showed higher percentage of callus induction $(91.50 \%$ ) with $2 \mathrm{mg} / \mathrm{l}$ 2,4-D supplemented Murashige and Skoog (MS) media. The same concentration of 2,4-D resulted in the maximum callus fresh $(0.56 \mathrm{~g})$ and dry weight $(0.39 \mathrm{~g})$ from leaf disc explant. Then the callus was transferred to untreated, $2.0 \mathrm{mg} / \mathrm{l}$ BAP + 0.2 mg/l NAA + $1.0 \mathrm{mg} / \mathrm{l} \mathrm{Kn}, 2.0 \mathrm{mg} / \mathrm{l} \mathrm{BAP}+1.0$ $\mathrm{mg} / \mathrm{l} \mathrm{NAA}+1.0 \mathrm{mg} / \mathrm{l} \mathrm{Kn}$ and $2.0 \mathrm{mg} / \mathrm{l} \mathrm{BAP}+1.5 \mathrm{mg} / \mathrm{l} \mathrm{NAA}+1.0 \mathrm{mg} / \mathrm{l} \mathrm{Kn}$ fortified MS medium. After transferring the callus of different explants to shoot regeneration media containing different concentrations of 6benzylaminopurine (BAP), 1-naphthaleneacetic acid (NAA) and Kinetin $(\mathrm{Kn})$, only cotyledon callus started to regenerate shoot. The combination of BAP $(2 \mathrm{mg} / \mathrm{l})+\mathrm{NAA}(0.2 \mathrm{mg} / \mathrm{l})+\mathrm{Kn}(1 \mathrm{mg} / \mathrm{l})$ showed highest shoot regeneration percentage $(67.77 \%)$ and the maximum number of shoots (5.12) per explant were recorded in the treatment combination of $2 \mathrm{mg} / \mathrm{l} \mathrm{BAP}$ $+0.2 \mathrm{mg} / \mathrm{l} \mathrm{NAA}+1 \mathrm{mg} / \mathrm{l} \mathrm{Kn}$. These results provided a basis for the optimization of the callus induction protocol of cucumber for genetic transformation.

Keywords: Callus induction, Cucumis sativus, Plant regeneration, 2,4Dichlorophenoxyacetic acid.

\section{INTRODUCTION}

Cucumber (Cucumis sativus. L.) is an important and commercially popular cucurbitaceous vegetable crop holding a very coveted position in the vegetable market. It is commercially represented by both pickling and fresh market cultivars all over the world [1]. This vegetable is very high in water content and very low in calories [2]. A fresh cucumber provides vitamin $\mathrm{C}$, niacin, iron, calcium, thiamine, fibers, phosphorus, and potassium [3]. It has potential antidiabetic, lipid-lowering, and antioxidant activity [2]. More than 50\% production of cucumber comes from Asia. Turkey, Iran, Uzbekistan, Japan, and Iraq are considered leading cucumber-producing countries [4].

Modern biotechnology intends to improve crops by means that are impossible by classical plant breeding [5]. Conventional techniques of crop improvement are lengthy
Published Online: October 19, 2021

ISSN: 2684-5199

DOI: 10.24018 / ejbio.2021.2.5.278

Hasina Sultana

Assistant Professor, Department of Horticulture, Bangabandhu Sheikh Mujibur Rahman Agricultural University, Gazipur, Bangladesh.

(e-mail: hsultana17@gmail.com)

Lutfun Nahar

Department of Horticulture, Bangabandhu Sheikh Mujibur Rahman Agricultural University, Gazipur, Bangladesh.

(e-mail: lutfun.nahar.ruchita ${ }^{\circledR}$ gmail.com) M. Mofazzal Hossain

Professor, Department of Horticulture, Bangabandhu Sheikh Mujibur Rahman Agricultural University, Gazipur, Bangladesh.

(e-mail: mdmofazzal.bsmrau@gmail.com) Totan Kumar Ghosh

Professor, Department of Crop Botany, Bangabandhu Sheikh Mujibur Rahman Agricultural University, Gazipur, Bangladesh.

(e-mail: totan@bsmrau.edu.bd)

Md. Sanaullah Biswas*

Professor, Department of Horticulture, Bangabandhu Sheikh Mujibur Rahman Agricultural University, Gazipur, Bangladesh.

(e-mail: sanaullah@bsmrau.edu.bd)

*Corresponding Author processes and have limited success. Plant tissue culture has often been hailed as one of the most significant potential areas for crop improvement and genetic transformation [6]. Callus induction via indirect organogenesis is one of the substantial steps for selecting the suitability of genotypes for tissue culture-based research [7]. Although indirect organogenesis is not only a valuable method for plant propagation, but it is also known as a powerful tool for plant genetic improvement, germplasm preservation, and production of beneficial secondary metabolites [8].

Cucumber is usually propagated by seeds. The improvement of this vegetable crop through conventional breeding techniques is complex and has several limitations [9]. Due to its high cross-pollination characteristics, this species is tough to propagate in vivo conditions. Moreover, there is an enormous variation in its pollination behaviour. [10]. In this case, plant tissue culture techniques such as in vitro callus induction and subsequent plant regeneration from 
callus tissue could be a very functional and promising technology to overcome the problem and can play a vital role in the rapid mass proliferation, new germplasm generation and conservation and overall potential use of this crop. Moreover, a suitable micropropagation protocol for cucumber could be used for reducing the cost of hybrid seed production, which can account for more than $30 \%$ of the total seedling cost [11].

The regeneration of cucumber plants has been reported either directly from nodal [11], [12] and shoot tip [13] explants or via callus that developed on anthers [14], cotyledons [15], hypocotyls [16], leaves [17], petioles [18] and protoplasts [19]. However, a large scale somaclonal variation in tissue culture-derived regenerants was found when plants were regenerated indirectly through somatic embryogenesis, cell suspensions, or isolated protoplast culture [20], [21]. Despite the availability of various reports on cucumber organogenesis and genetic transformation via indirect organogenesis, a careful perusal reveals that the frequency of regeneration or transformation was comparatively low. It was largely dependent on the nature of the explants, the cultivars, growth regulator combinations and physical conditions of culture. Studies already indicated that the success of cucumber regeneration was essentially genotype-dependent [22], [23]. Another study [24] reported that callus induction frequency, callus growth rate and nature of callus in cucumber were significantly affected by the type and concentration of the plant growth regulators and were significantly higher when incorporating auxins in the medium compared to cytokinins. Accordingly, the present study was undertaken to establish an efficient and reproducible protocol for callus induction in cucumber from cotyledon, hypocotyl, and leaf disc derived explants under different hormonal concentrations.

\section{MATERIALS AND MethodS}

\section{A. Seed Germination and Culture Condition}

Matured seeds of commercial cucumber were collected from the market for in vitro regeneration. The seeds were washed thoroughly under running tap water and surface sterilized with $0.1 \% \mathrm{HgCl}_{2}$ adding 4-5 drops of Tween-20 (a commercial detergent) for 15 minutes. These were rinsed with double distilled water five times and allowed to germinate on half-strength MS media [25] without plant growth regulators. The basal media was solidified by adding $8.0 \mathrm{~g} / \mathrm{l}$ agar. The $\mathrm{pH}$ of the media was adjusted to 5.8 before autoclaving for $15 \mathrm{~min}$ at $121{ }^{\circ} \mathrm{C}$ with $1.01 \mathrm{~kg} / \mathrm{cm}^{2}$ (15 PSI) pressure. The cultures were incubated at $25 \pm 1{ }^{\circ} \mathrm{C}$ under 16 hours light and 8 hours dark photoperiod with a light intensity 2000-3000 lux.

\section{B. Callus Induction}

The explants (cotyledons, hypocotyl and first pair of leaf, about $2-5 \mathrm{~mm}$ ) were excised from the in vitro raised seven day old health seedlings and transferred to the MS media supplemented with different concentrations $(0,0.5,2$ and $4 \mathrm{mg} / \mathrm{l})$ of 2,4-D for callus induction.

\section{Shoot Regeneration}

Five-week old callus of different explants (cotyledons, hypocotyl and leaf disc) were transferred to MS medium supplemented with different combinations of BAP, NAA and $\mathrm{Kn}$ (i.e. $0 \mathrm{mg} / \mathrm{l}$ as control, $2 \mathrm{mg} / \mathrm{l} \mathrm{BAP}+0.2 \mathrm{mg} / \mathrm{l} \mathrm{NAA}+1$ $\mathrm{mg} / \mathrm{l} \mathrm{Kn}, 2 \mathrm{mg} / \mathrm{l} \mathrm{BAP}+1 \mathrm{mg} / \mathrm{l} \mathrm{NAA}+1 \mathrm{mg} / \mathrm{Kn}$ and $2 \mathrm{mg} / \mathrm{l}$ $\mathrm{BAP}+1.5 \mathrm{mg} / \mathrm{l} \mathrm{NAA}+1 \mathrm{mg} / \mathrm{l} \mathrm{Kn}$ ) for shoot organogenesis. Cultures were subcultured on fresh media after 21 days of induction.

\section{Rooting and Acclimatization}

Regenerated shoots (about 3-4 cm) were excised and cultured on MS media fortified with $2 \mathrm{mg} / \mathrm{l}$ NAA for adventitious rooting. After 3 weeks, rooted plants were washed thoroughly in tap water and transplanted into polyethene pots containing autoclaved soil, sand and vermiculite mixture $(1: 2: 1)(\mathrm{v} / \mathrm{v} / \mathrm{v})$. Potted plants were grown in a growth chamber at $85 \%$ relative humidity. Plants were covered with polyethene covers for 2 weeks to maintain high humidity. Upon new leaf growth, the covers were removed, and hardened plants were transferred to the field.

\section{E. Statistical Analysis}

The study was conducted following Completely Randomized Design (CRD) with three replications. The average mean data were evaluated by ANOVA (analysis of variance) test, and the means were compared following least significant difference (LSD) test to determine the significant differences $(\mathrm{P}<0.05)$ using 'Statistix 10' software.

\section{RESULTS}

\section{A. Response of Explant to Callus Induction}

The MS medium supplemented with 2,4-D (0.5-4 mg/l) induced callus in all explants within 4-9 days (Table I). Among different explants explored for callus induction, leaf disc responded earlier (4.67 days) and showed higher callus induction $(91.50 \%)$ with $2 \mathrm{mg} / \mathrm{l}$ 2,4-D added media. The exact concentration also gave a better induction rate $(87.50 \%)$ in hypocotyl, whereas cotyledon performed well with $4 \mathrm{mg} / 1$ 2,4-D. No callus was observed in control.

\section{B. Characteristics of Callus}

Three types of calluses were observed in the explants and characterized based on the physical appearance: i) compact and light green in leaf disc, ii) friable and green in cotyledon and compact and brown in hypocotyl explant (Fig. 1).

TABLE I: Days to CALlus INITIATION AND CALlus INDUCTION PERCENTAGE IN VARIOUS EXPLANTS OF CUCUMBER ON MS MEDIUM SuPPLEMENTEd WITH VARIOUS CONCENTRATIONS OF 2,4-D

\begin{tabular}{|c|c|c|c|c|c|c|}
\hline \multirow{2}{*}{$\begin{array}{c}\text { 2,4-D concentration } \\
(\mathrm{mg} / \mathrm{l})\end{array}$} & \multicolumn{3}{|c|}{ Days to callus initiation } & \multicolumn{3}{|c|}{ Callus induction $(\%)$} \\
\hline & Hypocotyl & Cotyledon & Leaf disc & Hypocotyl & Cotyledon & Leaf disc \\
\hline 0 & - & - & - & - & - & - \\
\hline 0.5 & $9.67 \pm 0.88^{x}$ & $9.67 \pm 1.22$ & $5.33 \pm 0.88$ & $71.12 \pm 4.16$ & $67.33 \pm 4.06$ & $69.34 \pm 3.60$ \\
\hline 2.0 & $9.33 \pm 1.87$ & $7.33 \pm 0.88$ & $4.67 \pm 0.67$ & $87.50 \pm 5.29$ & $73.83 \pm 3.18$ & $91.50 \pm 1.76$ \\
\hline 4.0 & $8.33 \pm 1.45$ & $8.67 \pm 0.33$ & $4.67 \pm 0.88$ & $83.33 \pm 4.16$ & $85.00 \pm 4.36$ & $89.16 \pm 3.05$ \\
\hline
\end{tabular}

\footnotetext{
"_" indicate no callus induction observed. ${ }^{\mathrm{x}}$ The values are the means \pm standard error.
} 

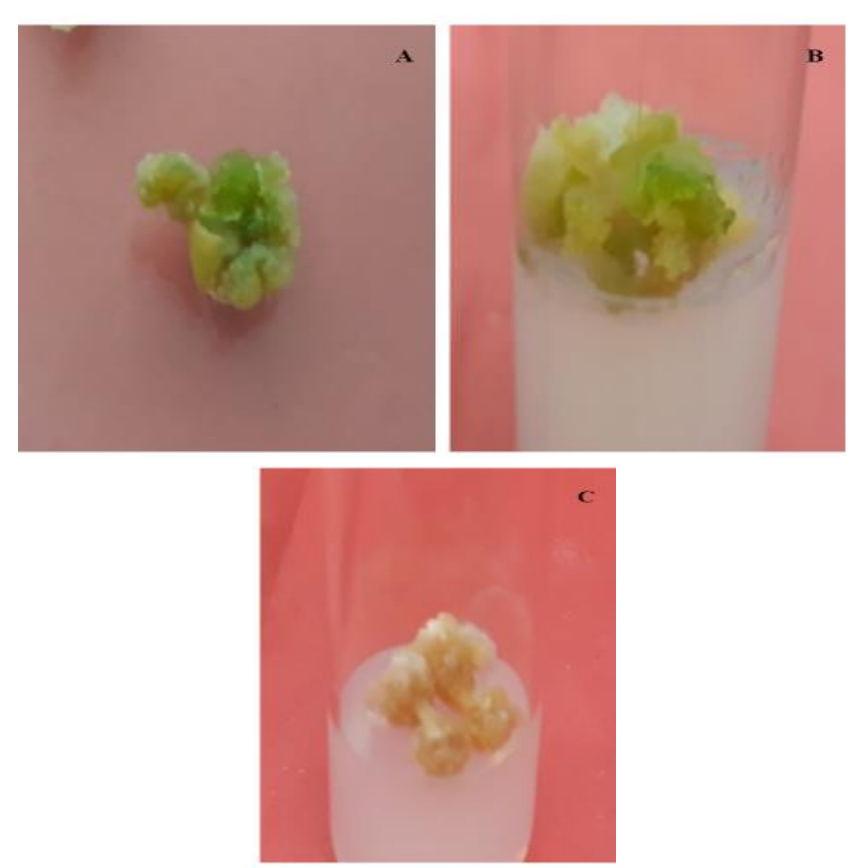

Fig. 1. Callus induced from A) cotyledon, B) leaf disc and C) hypocotyl explants of cucumber.

\section{Callus Fresh and Dry Weight}

Various concentrations of 2,4-D were observed to significantly impact the callus fresh and dry weight (Table II). The maximum fresh weight observed with $2.0 \mathrm{mg} / 1$ 2,4D in hypocotyl, cotyledon and leaf disc explant were 0.2093 , 0.3905 and $0.5552 \mathrm{~g}$, respectively. This concentration of 2,4$\mathrm{D}$ also resulted in significantly higher callus dry weight followed by $4 \mathrm{mg} / \mathrm{l}$ in all the explants tested and the lowest result was observed in control.

\section{Dry Matter Accumulation in Callus}

The results presented in Fig. 2 revealed that various concentrations of 2,4-D also showed significant differences in the dry matter accumulation in callus after 5 weeks of incubation. Among the explant tested, leaf disc explant accumulated maximum dry matter with 2,4-D at $2 \mathrm{mg} / \mathrm{l}$ followed by $4 \mathrm{mg} / \mathrm{l}$. Cotyledon explant also showed a higher accumulation of biomass, although the variation was insignificant with hypocotyl explants. The role of 2,4-D on the accumulation of biomass in explant enhance further regeneration of the plants.

\section{E. Shoot Regeneration}

After transferring the callus of different explants (cotyledons, hypocotyl, and leaf disc) to shooting media containing different BAP, NAA and $\mathrm{Kn}$, we found that hypocotyl and leaf disc callus was not a response. In contrast, only cotyledon callus started to regenerate shoot in all the treatments (Fig. 3). MS media supplemented with $2 \mathrm{mg} / \mathrm{l}$ $\mathrm{BAP}+0.2 \mathrm{mg} / \mathrm{l} \mathrm{NAA}+1 \mathrm{mg} / \mathrm{l} \mathrm{Kn}$ performed well with the highest percentage of shoot regeneration $(67.77 \%)$ and number of shoots per callus (5.12) while $2 \mathrm{mg} / \mathrm{l} \mathrm{BAP}+1.5$ $\mathrm{mg} / \mathrm{l} \mathrm{NAA}+1 \mathrm{mg} / \mathrm{l} \mathrm{Kn}$ amended medium responded earlier (36.55 days) to regenerate shoots than the other treatments (Table III). MS media without growth regulators showed a low response regarding all these regeneration aspects.

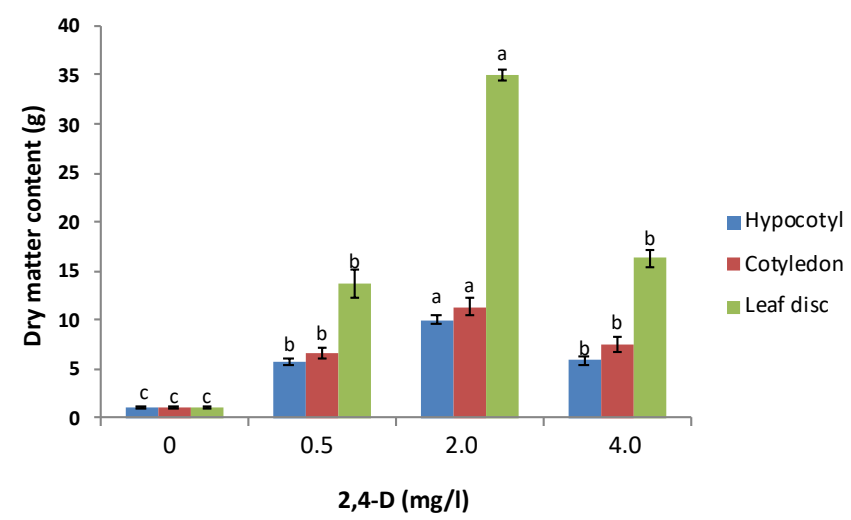

Fig. 2. Effect of various concentrations of 2,4-D on dry matter accumulation $(\mathrm{g})$ of different explants after 5 weeks. [Bars under each parameter with the same letter (s) are not significantly different at $\mathrm{P}<0.01$; error bars indicate standard deviation].
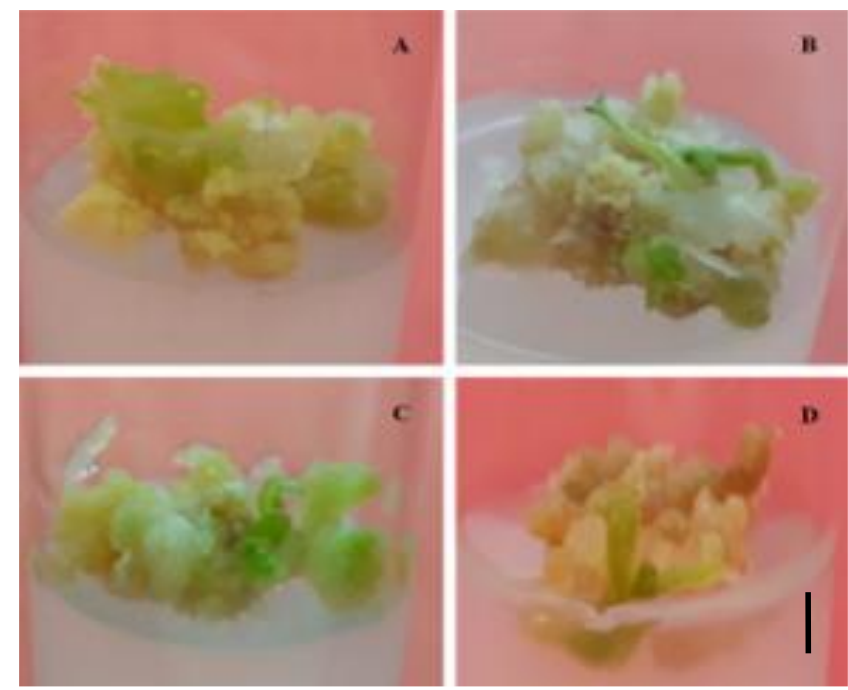

Fig. 3. Shoot regeneration from cotyledon callus on MS media supplemented with different concentrations of BAP, NAA and $\mathrm{Kn}$. A) Control. B) $2.0 \mathrm{mg} / \mathrm{l} \mathrm{BAP}+0.2 \mathrm{mg} / \mathrm{l} \mathrm{NAA}+1.0 \mathrm{mg} / \mathrm{l} \mathrm{Kn}$. C) $2.0 \mathrm{mg} / 1$ $\mathrm{BAP}+1.0 \mathrm{mg} / \mathrm{l} \mathrm{NAA}+1.0 \mathrm{mg} / \mathrm{l} \mathrm{Kn}$. D) $2.0 \mathrm{mg} / \mathrm{l} \mathrm{BAP}+1.5 \mathrm{mg} / \mathrm{l} \mathrm{NAA}+$ $1.0 \mathrm{mg} / \mathrm{K} \mathrm{Kn}$. Bar= $1 \mathrm{~cm}$.

\begin{tabular}{|c|c|c|c|c|c|c|}
\hline \multirow{2}{*}{$\begin{array}{l}\text { 2,4-D concentration } \\
(\mathrm{mg} / \mathrm{l})\end{array}$} & \multicolumn{2}{|c|}{ Hypocotyl } & \multicolumn{2}{|c|}{ Cotyledon } & \multicolumn{2}{|c|}{ Leaf disc } \\
\hline & $\begin{array}{c}\text { Fresh weight } \\
(\mathrm{g})\end{array}$ & Dry weight (g) & $\begin{array}{c}\text { Fresh weight } \\
(\mathrm{g})\end{array}$ & Dry weight $(\mathrm{g})$ & $\begin{array}{c}\text { Fresh weight } \\
(\mathrm{g})\end{array}$ & Dry weight $(\mathrm{g})$ \\
\hline 0 & $0.0171^{\mathrm{c}}$ & $0.0009^{c}$ & $0.0294^{\mathrm{c}}$ & $0.0025^{\mathrm{c}}$ & $0.0093^{\mathrm{c}}$ & $0.0009^{c}$ \\
\hline 0.5 & $0.1734^{\mathrm{b}}$ & $0.00523^{\mathrm{b}}$ & $0.2702^{\mathrm{b}}$ & $0.0125^{\mathrm{b}}$ & $0.3595^{\mathrm{b}}$ & $0.0127^{\mathrm{b}}$ \\
\hline 2.0 & $0.2093^{\mathrm{a}}$ & $0.00924^{\mathrm{a}}$ & $0.3905^{\mathrm{a}}$ & $0.0263^{\mathrm{a}}$ & $0.5552^{\mathrm{a}}$ & $0.0324^{\mathrm{a}}$ \\
\hline 4.0 & $0.1600^{\mathrm{b}}$ & $0.0054^{\mathrm{b}}$ & $0.3652^{\mathrm{a}}$ & $0.0160^{\mathrm{b}}$ & $0.3637^{b}$ & $0.0150^{\mathrm{b}}$ \\
\hline CV (\%) & 8.64 & 17.13 & 6.23 & 15.20 & 11.34 & 11.18 \\
\hline $\operatorname{LSD}(0.05)$ & 0.023 & 0.001 & 0.031 & 0.004 & 0.068 & 0.003 \\
\hline
\end{tabular}

The column means under each parameter with the same letter (s) are not significantly different at $\mathrm{P}<0.05$. 
TABLE III: EFFECT OF DIFFERENT COMBINATIONS OF BAP, NAA AND KN ON SHOOT REGENERATION FROM COTYLEDON EXPLANT OF CUCUMBER

\begin{tabular}{cccc}
\hline Treatment & $\begin{array}{c}\text { Shoot } \\
\text { regeneration } \\
(\%)\end{array}$ & $\begin{array}{c}\text { Days to shoot } \\
\text { regeneration }\end{array}$ & $\begin{array}{c}\text { No. of } \\
\text { shoot/callus }\end{array}$ \\
\hline $\mathrm{T}_{0}$ & $3.33 \mathrm{~d}$ & $55.88 \mathrm{a}$ & $0.33 \mathrm{~d}$ \\
$\mathrm{~T}_{1}$ & $67.77 \mathrm{a}$ & $48.55 \mathrm{~b}$ & $5.12 \mathrm{a}$ \\
$\mathrm{T}_{2}$ & $51.12 \mathrm{~b}$ & $43.88 \mathrm{c}$ & $3.99 \mathrm{~b}$ \\
$\mathrm{~T}_{3}$ & $25.55 \mathrm{c}$ & $36.55 \mathrm{~d}$ & $1.55 \mathrm{c}$ \\
$\mathrm{CV}(\%)$ & 12.76 & 3.17 & 15.63 \\
$\mathrm{LSD}(0.05)$ & 8.87 & 2.75 & 0.81 \\
\hline
\end{tabular}

$\mathrm{T}_{0}=$ control, $\mathrm{T}_{1}=2 \mathrm{mg} / \mathrm{BAP}+0.2 \mathrm{mg} / \mathrm{l} \mathrm{NAA}+1 \mathrm{mg} / \mathrm{l} \mathrm{Kn}, \mathrm{T}_{2}=2 \mathrm{mg} /$ $\mathrm{BAP}+1 \mathrm{mg} / \mathrm{l} \mathrm{NAA}+1 \mathrm{mg} / \mathrm{l} \mathrm{Kn}, \mathrm{T}_{3}=2 \mathrm{mg} / \mathrm{l} \mathrm{BAP}+1.5 \mathrm{mg} / \mathrm{l} \mathrm{NAA}+1 \mathrm{mg} / \mathrm{l}$ $\mathrm{Kn}$. [The column means under each parameter with the same letter (s) are not significantly different at $\mathrm{P}<0.05]$.

\section{DISCUSSION}

All the explants of cucumber showed differential response to various concentrations of 2,4-D within 4-9 days of induction. The MS media divide of PGR's did not induce callus and therefore treated as control, affirming those plant growth regulators (PGR) is crucial for inducing callus in cucumber. However, the type of response was dependent on both explant and level of 2,4-D of the media. Concerning callus induction time, the shorter period was recorded in leaf disc derived explant than the other explants in MS media supplemented with 2,4-D at $2 \mathrm{mg} / \mathrm{l}$. The exact concentration showed a better result in callus induction percentage in hypocotyl and leaf disc derived explants. Previously it is reported that cucumber leaves [26] and hypocotyl explants of summer squash [27] produced callus in the presence of 2,4-D from $2-3 \mathrm{mg} / \mathrm{l}$ concentration. This study fine-tuned the 2,4-D and best explant concentrations to establish an effective callus induction protocol for future biotechnological work.

Different explants produced callus of a different structure in the callus induction media. Compact and light green callus was produced in leaf disc while friable and green in cotyledon and compact and brown in hypocotyl explants. This variability was probably due to different tissue origins.

Results from weight measurements indicated a significant difference in weights of callus among the hormonal treatments. The increase of 2,4-D concentration up to 2.0 $\mathrm{mg} / \mathrm{l}$ significantly increased both calli fresh and dry weight, and a further increase in concentration showed a declining trend. The highest mean of fresh and dry weight was observed with $2.0 \mathrm{mg} / \mathrm{l}$ 2,4-D followed by $4.0 \mathrm{mg} / \mathrm{l}$ in most cases. The observation is in line with the observation of [28]. Several studies have also reported that the leaf disc explant performed the best regarding callus the fresh and dry weight in other cucurbits [29], [1].

A tendency for increased dry matter accumulation of callus was detected for all the explants in the presence of 2,4-D up to $2.0 \mathrm{mg} / \mathrm{l}$ concentration, and leaf disc derived explant was more responsive than the other explants.

In vitro induction of organogenesis depends on the endogenous concentration of plant growth regulators, their distribution in the cultured tissue and interaction with exogenously supplied growth regulators [27]. However, regeneration of cucurbits is comparatively low and dependent on the nature of explants [30], [23], growth regulator combinations, and physical conditions of culture [31]. In the present study, the shoot was successfully induced only from the cotyledon derived callus in all treatments after transferring to shoot regeneration media containing different concentrations of BAP, NAA and $\mathrm{Kn}$. The results indicated that NAA at low concentrations $(0.2 \mathrm{mg} / \mathrm{l})$ combined with BA and $\mathrm{Kn}$ effectively increased shoot regeneration percentage and number of shoots per callus, whereas high doses of NAA $(1.0-1.5 \mathrm{mg} / \mathrm{l})$ had adverse effects on organogenesis. A combination of $2.0 \mathrm{mg} / \mathrm{l} \mathrm{BAP}+1.5 \mathrm{mg} / \mathrm{l} \mathrm{NAA}+1.0 \mathrm{mg} / \mathrm{l} \mathrm{Kn}$ was observed to regenerate shoot within a shorter period than the other hormonal combinations. A similar study [32] reported $75.6 \%$ shoot regeneration in cucumber when 8.88 $\mu \mathrm{M}$ BAP, $1.34 \mu \mathrm{M}$ NAA, $0.91 \mu \mathrm{M}$ Zeatin and $136.85 \mu \mathrm{M}$ Lglutamine were supplemented with MS media. In watermelon, $56.67 \%$ shoot regeneration with $2 \mathrm{mg} / \mathrm{l}$ BAP and $0.2 \mathrm{mg} / \mathrm{l} \mathrm{NAA}$ has also been reported [33], whereas $80 \%$ shoot regeneration and 5.00 shoot regeneration per callus were obtained with $2.0 \mathrm{mg} / \mathrm{l} \mathrm{BAP}$ and $0.5 \mathrm{mg} / \mathrm{l} \mathrm{NAA} \mathrm{[34].}$

\section{CONCLUSIONS}

Based on the above findings, it can be concluded that 2,4$\mathrm{D}$ is an efficient growth regulator to induce callus formation in cucumber. Among the various concentrations tested 2,4-D at $2.0 \mathrm{mg} / \mathrm{l}$ was found to be the best hormonal concentration regarding callus induction features in all cucumber explants. Notably, only cotyledon explant induced adventitious shoots among the explants, and a high frequency of shoots regeneration was achieved from the treatment combination of BAP at $2.0 \mathrm{mg} / \mathrm{l}$, NAA at $0.2 \mathrm{mg} / \mathrm{l}$ and $\mathrm{Kn}$ at $1.0 \mathrm{mg} / \mathrm{l}$. However, cytological studies can reveal the causes of the potentiality of cotyledon explants to regenerate plants that we are doing in our present study. The results reported in this study on the regeneration protocol are expected to contribute to genetic transformation work in cucumber.

\section{REFERENCES}

[1] I. I. Lashin, and D. Mamdouh, "Effect of plant growth regulators on callus induction and plant regeneration of cucumber (Cucumis sativus L. Beith Alpha)", Nature Sci., 12(11), pp. 68-74, 2014.

[2] P. K. Mukherjee, N. K. Nema, N. Maity, and B. K. Sarkar, "Phytochemical and therapeutic potential of cucumber", Fitoterapia, 84, pp. 227-236, 2013.

[3] L. Aziza, A. H. Fardous, Y. Farjana, and R. H. Hasibur, "Production and marketing of cucumber in some selected areas of Mymensingh district”, Agric. Res. Technol., 15(5), pp. 141-148, 2018.

[4] Z. Khan, A. H. Shah, R. Gul, A. Majid, and U. Khan, "Morphoagronomic characterization of cucumber germplasm for yield and yield associated traits", Int. J. Agron. Agr. Res., 6, pp. 1-6, 2015.

[5] V. Gaba, A. Zelcer, and A. Gal-on, "Cucurbit biotechnology- the importance of virus resistance", In Vitro Cell Dev. Biol. -Plant, 40, pp. 346-358, 2004

[6] V. P. Sobhakumari, and S. D. Mathew, "Effect of hybrid vigor on callus induction and regeneration of sugarcane", Cytologia, 74(1), pp. 71-77, 2009.

[7] N. Carsono, and T. Yoshida, "Identification of callus induction potential of 15 Indonesian rice genotypes", Plant Prod. Sci., 9(1), pp. 65-70, 2006.

[8] M. Hesami, and M.H. Daneshvar, "In Vitro adventitious shoot regeneration through direct and indirect organogenesis from seedlingderived hypocotyl segments of Ficus religiosa L.: An important medicinal plant", Hort. Sci., 53(1), pp. 55-61, 2018.

[9] T. D. Thomas, and K. R. Sreejesh, "Callus induction and plant regeneration from cotyledonary explants of ash gourd (Benincasa hispida L.)", Sci. Hort., 100(1), pp. 359-367, 2004.

[10] J. R. Deakin, G. W. Bohn, and T. W. Whitaker, "Interspecific hybridization in Cucumis", Econ. Bot., 25(2), pp. 195-211, 1971.

[11] J. Konstas, and S. Kintzios, "Developing a scale-up system for the micropropagation of cucumber (Cucumis sativus L.): The effect of 
growth retardants, liquid culture and vessel size", Plant Cell Reprod., 21(6), pp. 538-548, 2003.

[12] A. Ahmad, and M. Anis, "In vitro mass propagation of Cucumis sativus L. from nodal segments", Turk. J. Bot., 29, pp. 237-240, 2005.

[13] A. Vasudevan, N. Selvaraj, A. Ganapathi, S. Kasthurirengan, V. R. Anbazhagan, and M. Manickavasagam, "Glutamine: A suitable nitrogen source for enhanced shoot multiplication in Cucumis sativus L.”, Biol. Plant, 48, pp. 125-128, 2004.

[14] H. A. Kumar, H. N. Murthy, and K. Y. Paek, "Embryogenesis and plant regeneration from anther cultures of Cucumis sativus L.", Sci. Hort., 98(3), pp. 213-222, 2003.

[15] C. Zhu, and Z. Chen, "Role of polyamines in adventitious shoot morphogenesis from cotyledons of cucumber in vitro", Plant Cell Tis. Org. Cult., 81, pp. 45-53, 2005.

[16] N. Selvaraj, A. Vasudevan, M. Manickavasagam, and A. Ganapathi, "In vitro organogenesis and plant formation in cucumber", Biol. Plantarum, 50(1), pp. 123-126, 2006.

[17] W. Burza, and S. Malepszy, "Direct plant regeneration from leaf explants in cucumber (Cucumis sativus L.) is free of stable genetic variation", Plant Breed., 114, pp. 341-345, 1995a.

[18] Z. K.Punja, N. Abbas, G. G. Sarmento, and F. A. Tang, "Regeneration of Cucumis sativus var. sativus and C. sativus var. hardwickii, C. melo, and $C$. metuliferus from explants through somatic embryogenesis and organogenesis", Plant Cell Tis. Org. Cult., 21(2), pp. 93-102, 1990.

[19] W. BURZA, and S. MALEPSZY, "In vitro culture of Cucumis sativus L. XVIII. Plants from Protoplasts through direct somatic embryogenesis", Plant Cell Tis. Org. Cult., 41, pp. 259-266, 1995 b.

[20] M. Ladyzynski, W. Burza, and S. Malepszy, "Relationship between somaclonal variation and type of culture in cucumber", Euphytica., 125, pp. 349-356, 2002.

[21] M. Filipecki, A. Wisniewska, Z. Yin, and S. Malepszy, "The heritable changes in metabolic profiles of plants regenerated in different types of in vitro culture", Plant Cell Tis. Org. Cult., 82, pp. 349-356, 2005.

[22] T. C. Wehner, and R. D. Locy, "In vitro adventitious shoot and root formation of cultivars and lines of Cucumis sativus L.", Hort. Sci. 16, pp. 759-760, 1981a.

[23] S. G. Kim, J. R. Chang, H. C. Cha, and K. W. Lee, "Callus growth and plant regeneration in diverse cultivars of cucumber (Cucumis sativus L.)", Plant Cell Tis. Org. Cult., 12, pp. 67-74, 1988.

[24] S. Abu-Romman, M. Suwwan, and E. Al Ramamneh, "The influence of plant growth regulators on callus induction from hypocotyls of cucumber (Cucumis sativus L.)", Adv. Environ. Biol., 7(2), pp. 339$343,2013$.

[25] T. Murashige, and T. Skoog, "A revised medium for rapid growth and bioassays with tobacco tissue cultures", Physiol. Plantarum, 15, pp. 473-497, 1962.

[26] M. Usman, Z. Hussain, and B. Fatima, "Somatic embryogenesis and shoot regeneration induced in cucumber leaves", Pakistan J. Bot. 43(2), pp. 1283-1293, 2011.

[27] S. P. Pal, I. Alam, M. Anisuzzaman, K. K. Sarker, S. A. Sharmin, and M. F. Alam, "Indirect organogenesis in summer squash (Cucurbita pepo L.)”, Turk. J. Agric. Forestry, 31(1), pp. 63-70, 2007.

[28] B. Tuncer, "Callus proliferation and shoot regeneration from different explant types in ornamental gourd (Cucurbita pepo var. ovifera)", Yüzüncü Yll Üniversitesi Tarım Bilimleri Dergisi, 23(2), pp. 164-171, 2013.

[29] N. K. Devendra, B. Subhash, and Y. N. Seetharam, "Callus growth and plant regeneration in Momordica dioica (Roxb.) wild cucurbitaceae", Am.-Eurasian J. Sustain. Agric, 3(4), pp. 743-748, 2009.

[30] T. C. Wehner, and R. D. Locy, "Tissue culture propagation of field grown cucumber selections", Cucurbit Genet. Cooperative Rep., 4, pp. 20-22, 1981b.

[31] C. Rakhi, H. R. Rekha, and M. V. Kumar, “Assessment of regenerative potentiality of cotyledon explants of some indigenous varieties of cucurbits using varied concentrations of cytokinins", Sixth Int. Plant Tis. Cult. Biotechnol. Conference Proc, pp. 27-40, 2010.

[32] N. Selvaraj, A. Vasudevan, M. Manickavasagam, S. Kasthurirengan, and A. Ganapathi, "High frequency shoot regeneration from cotyledon explants of cucumber via organogenesis", Sci. Hort., 112(1), pp. 2-8, 2007.

[33] M. Rasheed, M. J. jaskani, M. Rasheed, M. S. Iqbal, S. Zia-Ul-Hasan, R. Rafique, and M. Iqbal, "Regeneration of plantlets from various explants of tetraploid watermelon", J. Biol. Agric. Health, 3(1), pp. 22 $29,2013$.

[34] M. M. Khatun, M. S. Hossain, M. Khalekuzzaman, A. Rownaq, and M. Rahman, "In vitro plant regeneration from cotyledon and internodes derived callus in watermelon (Citrulus lanatus Thumb.)", Int. J. Sustain. Crop Prod, 5(4), pp. 25-29, 2010. 